\title{
JEKK
}

Jurnal Epidemiologi Kesehatan Komunitas

2 (1), 2017, 27-35

\section{Beberapa Faktor yang Berpengaruh terhadap Barotrauma Membran Timpani pada Penyelam Tradisional di Wilayah Kabupaten Banyuwangi}

\author{
Sugianto ${ }^{*}$,Suharyo Hadisaputro ${ }^{* *}$, Supriharti ${ }^{* * *}$, Munasik $^{* * * *}$, M. Sakundarno Adi ${ }^{* * * *}$ \\ *Kantor Kesehatan Pelabuhan Kelas II Probolinggo, ${ }^{* *}$ Politeknik Kesehatan Semarang, ${ }^{* * *}$ Fakultas \\ Kedokteran Universitas Diponegoro, ${ }^{* * * *}$ Fakultas Perikanan dan Ilmu Kelautan, ${ }^{* * * * *}$ Fakultas Kesehatan \\ Masyarakat Universitas Diponegoro
}

\begin{abstract}
Background: Tympanic membrane barotraumas is a rupture of tissue structure and its sequel. The initial research results show that there was $39.7 \%$ of tympanic membrane prevalence. The aim of the research was to prove the effect of several internal and external factors in traditional divers on tympanic membrane barotraumas.

Method: The design used was cross sectional study strengthened by in-depth interview. The number of respondent was 130 from two groups of traditional divers taken in proportional stratified random sampling. The data analysis were univariate, bivariate, and multivariate.

Results: The variables proven as the risk factors in the group of the divers who hold their breath for coins were the dive descending speed 18 meter per $(\mathrm{p}=0.012)$ and without diving equipments $(p=0.018)$. In the group of the divers using air compressor, the significant variables were the age of the divers in older adult 37 years old $(\mathrm{p}=0.025)$.

Conclusion: Several factors influencing tympanic membrane barotraumas in the group of the traditional divers who hold their breath for coins were ascending speed 18 meters per minute and without diving equipments with the probability of $39 \%$. In the group with air compressor, the variable was the age of older adult divers $\geq 37$ years with the probability of $98 \%$.
\end{abstract}

Keywords: Traditional diver; tympanic membrane barotraumas; riskfactor

Penulis korespondensi : sugiyantowahyuning@yahoo.com 


\section{Pendahuluan}

Indonesia merupakan negara kepulauan dengan panjang garis pantai $95.181 \mathrm{~km}^{2}$. Luas $2 / 3$ wilayah kedaulatan berupa laut yang luas perairannya sekitar $3.272 .000 \mathrm{~km}^{2}$, dengan jumlah pulau 13.466 yang tersebar dari Sabang sampai Merauke. Laut merupakan sumber kekayaan alam yang melimpah sehingga diperlukan sumber daya manusia yang trampil dalam bidang kelautan khususnya penyelaman. Laut selain sebagai jalur transportasi, obyek wisata juga sebagai sumber matapencaharian masyarakat Pelabuhan, pesisir dan kepulauan. ${ }^{2}$

Mata pencaharian masyarakat pelabuhan, pesisir dan kepulauan adalah sebagai nelayan penyelam tradisional. Masyarakat di lingkungan Pelabuhan penyebrangan mengantungkan pekerjaan di kapal sebagai tenaga kasar, buruh pelabuhan, dan juga sebagai penyelam tradisional tahan nafas. Penyelam tradisional tersebut mayoritas belum pernah mengikuti pendidikan dan pelatihan penyelaman secara formal karena keterbatasan dana dan minimnya sosialisasi dari pihak berwenang. Nelayan penyelam tradisional maupun penyelam tradisional pada umumnya melakukan penyelaman tahan nafas dan menggunakan alat bantu selam kompresor udara. Pekerjaan penyelam tradisional mempunyai tingkat risiko yang sangat tinggi terhadap kesehatan maupun keselamatan kerja sehingga diperlukan pengetahuan dan ketrampilan penyelaman yang benar. Kecerobohan dalam penyelaman dapat mengakibatkan terjadinya barotrauma atau ruptur membran timpani berdampak pada penurunanan ambang dengar. 3

Barotrauma membran timpani merupakan kerusakan struktur jaringan dan sekuelenya yang terjadi akibat ketidakmampuan menyamakan perubahan tekanan udara dalam rongga telinga tengah dengan lingkungan sekitarnya. Barotrauma bersifat sementara tetapi bila sering atau berulang dalam periode lama dapat berakibat irreversible. ${ }^{6,7}$ Data menunjukkan bahwa kejadian barotrauma membran timpani di Amerika untuk penyelaman militer sebesar
$(0,026 \%)$, penyelam rekreasi bawah laut sebesar $(0,034 \%)$ dan penyelam komersial $(0,36 \%)$ setiap tahunnya. ${ }^{8}$ Data yang di kumpulkan DepKes. R.I dari 10 Propinsi sampai dengan tahun 2008, terdapat 1.028 penyelam tradisional yang di wawancarai secara langsung di temukan penyakit dengan gejala klinis akibat penyelaman 93,9\%, yang terdiri dari gangguan pendengaran ringan sampai ketulian 39,7\%. ${ }^{9}$

Studi yang dilakukan pada nelayan penyelam tradisional kompresor udara menunjukkan kejadian barotrauma membran timpani dengan kedalaman penyelaman dan lama menyelam sebesar $32,43 \%$ dan tidak terjadi barotrauma membran timpani sebesar $67,56 \%{ }^{10}$ Para penyelam tradisional tahan nafas pengais uang logam maupun kompresor udara mayoritas mengeluh telinganya sakit, dan mengeluarkan cairan sampai pendengaran berkurang. Penyelam tradisional tersebut diduga di dominasi anakanak sampai orang dewasa tua yang berasal dari Desa Ketapang dan Bangsring. Laut merupakan sumber matapencaharian mereka di samping itu Pelabuhan Ketapang Banyuwangi sebagai sumber penghasilan tambahan untuk keperluan kebutuhan seharihari, wilayah tersebut masuk Kecamatan Kalipuro Kabupaten Banyuwangi. ${ }^{11}$

Studi pendahuluan dilakukan pada penyelam tradisional di Desa Ketapang dan Bangsring Kabupaten Banyuwangi, di peroleh hasil wawancara pada 30 penyelam tradisional menggambarkan bahwa 13 penyelam $(43,3 \%)$ sakit telinga, 8 penyelam $(26,7 \%)$ sakit persendian, 6 penyelam $(20 \%)$ sakit mata dan 3 peyelam (10\%) pusing.

\section{Metode}

Jenis penelitian ini adalah observasional analitik dengan desain cross sectional study dan di tunjang dengan pendekatan kualitatif melalui indepth interview. ${ }^{12}$ Studi ini bertujuan untuk mencari pengaruh antara variabel independent terhadap variabel dependent dengan melakukan pengukuran sesaat. Pemeriksaan penyelam tradisional di lakukan setelah observasi dan pengukuran sesaat. ${ }^{13}$ 
Populasi studi semua penyelam tradisional tahan nafas pengais uang logam maupun kompresor udara yang berdomisili di Desa Ketapang dan Bangsring wilayah Kabupaten Banyuwangi. Besar sampel yaitu 130 penyelam tradisional dari kedua kelompok, metode yang digunakan proportional statified random sampling dengan cara ramdom sampling dimana setiap penyelam tradisional yang memenuhi kriteria inklusi dimasukan dalam sampel penelitian sehingga total minimal sampel terpenuhi. Indepth intervew dilakukan terhadap 10\% dari kedu kelompok penyelam tradisional yang berdomisili di dua Desa.

Variabel dependent dalam penelitian ini adalah barotrauma membran timpani sedangkan variabel independent yaitu usia penyelam, indeks masa tubuh (IMT), lama bekerja, tingkat pendidikan penyelam, tingkat pengetahuan SOP safety dive, frekuensi penyelaman, kecepatan turun $\geq 18$ meter permenit, kecepatan naik $\geq 18$ meter permenit, kedalaman penyelaman, alat bantu selam, dan penghasilan penyelam.

\section{Hasil}

\section{Karakteristik Responden}

\section{Distribusi kelompok penyelam}

Distribusi kelompok penyelam tradisional lebih banyak pada penyelam tahan nafas pengais uang logam $(50,8 \%)$ dibandingkan penyelam kompresor udara $(49,2 \%)$.

\section{Distribusi Frekuensi Usia Responden}

Distribusi usia penyelam tradisionaal tahan nafas pengais uang logam di Pelabuhan Ketapang Banyuwangi rerata adalah 17,5 tahun, dengan usia termuda 12 tahun dan usia tertua 45 tahun dibandingkan penyelam kompresor udara rerata usia 37 tahun dengan usia termuda 24 tahun dan usia tertua 48 tahun.

\section{Distribusi Berdasarkan Indeks Masa Tubuh (IMT) Penyelam}

Distribusi IMT penyelam tradisional tahan nafas pengais uang logam maupun penyelam kompresor udara mayoritas IMT normal.

\section{Distribusi Lama Bekerja Penyelam}

Distribusi lama bekerja penyelam tradisionaal tahan nafas pengais uang logam di Pelabuhan Ketapang Banyuwangi rerata adalah 5,5 tahun, baru bekerja 2 tahun dan lama bekerja 22 tahun dibandingkan penyelam kompresor udara rerata 8 tahun, baru bekerja 3 tahun dan lama bekerja 23 tahun.

\section{Distribusi Frekuensi Pendidikan Penyelam}

Mayoritas penyelam tradisional tahan nafas pengais uang logam maupun penyelam kompresor udara adalah berpendidikan lulusan sekolah dasar (SD). Sedangkan prosentase ditingkat SMP-SMA adalah hampir sama rendahnya.

\section{Distribusi jenis barotrauma}

Jenis barotrauma membran timpani pada penyelam tradisional tahan nafas pengais uang logam maupun penyelam kompresor udara adalah barotrauma telinga tengah.

\section{Derajat barotrauma}

Mayoritas derajat barotrauma membran timpani pada penyelam tradisional tahan nafas pengais uang logam maupun penyelam kompresor udara adalah derajat 0 . Dapat dilihat pada Tabel 1.

\section{Analisis Bivariat}

Analisis bivariat dimaksudkan untuk mengetahui hubungan dan besarnya nilai ratio prevalence (RP) dengan dependent variabel kejadian barotrauma membran timpani dengan tingkat kemaknaan 95\%. Secara lengkap distribusi faktor risiko pada kelompok penyelam tahan nafas pengais uang logam dapat di lihat pada Tabel 2.

Analisis bivariat dimaksudkan untuk mengetahui hubungan dan besarnya nilai 
ratio prevalence (RP) terhadap kejadian barotrauma membran timpani dengan tingkat kemaknaan 95\%. Secara lengkap distribusi faktor risiko pada kelompok penyelam kompresor udara dapat di lihat pada Tabel 3.

\section{Analisis Multivariat}

Hasil analisis multivariat menunjukkan bahwa dari delapan variabel kandidat yang dianalisis secara bersamasama (metode Enter) terdapat dua variabel yang berhubungan yang terbukti secara statistik berpengaruh terhadap kejadian, barotrauma membran timpani yaitu kecepatan turun 18 meter permenit dan tidak memakai alat bantu selam (mask snorkel dan fins). Hasil analisis selengkapnya dapat dilihat pada Tabel 4.

Hasil analisis multivariat menunjukkan bahwa dari enam variabel kandidat yang dianalisis secara bersamasama (metode Enter) terdapat satu variabel yang berhubungan yang terbukti secara statistik berpengaruh terhadap kejadian barotrauma membran timpani yaitu usia penyelam dewasa tua 37 tahun. Hasil analisis selengkapnya dapat dilihat pada Tabel 5 .

Tabel 1. Karakteristik subyek penelitian

\begin{tabular}{|c|c|c|c|c|}
\hline \multirow[t]{2}{*}{ Karakteristik Subyek } & \multicolumn{2}{|c|}{$\begin{array}{l}\text { Penyelam Tahan Nafas } \\
\text { Pengais Uang Logam }\end{array}$} & \multicolumn{2}{|c|}{$\begin{array}{c}\text { Penyelam Kompresor } \\
\text { Udara }\end{array}$} \\
\hline & Jumlah & $\%$ & Jumlah & $\%$ \\
\hline \multicolumn{5}{|l|}{ 1. Jenis Kelamin } \\
\hline Tahan nafas & 66 & 100 & - & - \\
\hline Kompresor udara & - & - & 64 & 100 \\
\hline \multicolumn{5}{|l|}{ 2. Umur } \\
\hline$>12-20$ tahun & 33 & 50,0 & 0 & 0 \\
\hline 21-30 tahun & 30 & 45,5 & 14 & 21,9 \\
\hline 31-40 tahun & 2 & 3,0 & 36 & 56,2 \\
\hline $41-50$ tahun & 1 & 1,5 & 14 & 21,9 \\
\hline \multicolumn{5}{|l|}{ 4. Pengetahuan } \\
\hline Underweight $\left(<18,5 \mathrm{~kg} / \mathrm{m}^{2}\right)$ & 28 & 42,4 & 7 & 10,9 \\
\hline Normal $\left(\geq 18,5-22,9 \mathrm{~kg} / \mathrm{m}^{2}\right)$ & 30 & 45,4 & 20 & 31,2 \\
\hline Overweight $\left(\geq 23 \mathrm{~kg} / \mathrm{m}^{2}\right)$ & 4 & 6,1 & 8 & 12,5 \\
\hline At Risk $\left(23,0-24,9 \mathrm{~kg} / \mathrm{m}^{2}\right)$ & 2 & 3,0 & 5 & 7,8 \\
\hline Obese I $\left(25-29,9 \mathrm{~kg} / \mathrm{m}^{2}\right)$ & 2 & 3,0 & 14 & 21,9 \\
\hline Obese II $\left(30,0 \mathrm{~kg} / \mathrm{m}^{2}\right)$ & 0 & 0 & 10 & 15,6 \\
\hline \multicolumn{5}{|l|}{ 7. Kriteria Lama Bekerja } \\
\hline $0-5$ tahun & 33 & 50,0 & 18 & 28,1 \\
\hline 6-10 tahun & 20 & 30,3 & 18 & 28,1 \\
\hline 11-20 tahun & 10 & 15,2 & 27 & 42,2 \\
\hline 21-30 tahun & 3 & 4,5 & 1 & 1,6 \\
\hline \multicolumn{5}{|l|}{ 8. Tingkat Pendidikan } \\
\hline SD & 44 & 66,7 & 39 & 24 \\
\hline SMP & 21 & 31,8 & 23 & 19 \\
\hline SMA & 1 & 1,5 & 2 & 19 \\
\hline \multicolumn{5}{|l|}{ 9. Pengetahuan SOP } \\
\hline Kurang baik (skor < 66) & 43 & 65,16 & 49 & 7 \\
\hline Baik (skor 66) & 23 & 34,84 & 15 & 36 \\
\hline
\end{tabular}




\begin{tabular}{|c|c|c|c|c|}
\hline \multirow{2}{*}{ Karakteristik Subyek } & \multicolumn{2}{|c|}{$\begin{array}{l}\text { Penyelam Tahan Nafas } \\
\text { Pengais Uang Logam }\end{array}$} & \multicolumn{2}{|c|}{$\begin{array}{l}\text { Penyelam Kompresor } \\
\text { Udara }\end{array}$} \\
\hline & Jumlah & $\%$ & Jumlah & $\%$ \\
\hline \multicolumn{5}{|l|}{ 10. Jenis Barotrauma } \\
\hline Telinga luar & 0 & - & - & 0 \\
\hline Telinga tengah & 33 & 100 & 40 & 100 \\
\hline Telinga dalam & 0 & - & - & 0 \\
\hline \multicolumn{5}{|l|}{ 11. Derajat barotrauma } \\
\hline Telinga luar & 24 & 72,7 & 18 & 45 \\
\hline Telinga tengah & 6 & 18,3 & 17 & 42,5 \\
\hline Telinga dalam & 2 & 6 & 3 & 7,5 \\
\hline Underweight $\left(<18,5 \mathrm{~kg} / \mathrm{m}^{2}\right)$ & 0 & 0 & 1 & 2,5 \\
\hline Normal $\left(\geq 18,5-22,9 \mathrm{~kg} / \mathrm{m}^{2}\right)$ & 0 & 0 & 0 & 0 \\
\hline Overweight $\left(\geq 23 \mathrm{~kg} / \mathrm{m}^{2}\right)$ & 1 & 3 & 1 & 2,5 \\
\hline
\end{tabular}

Tabel 2. Distribusi faktor risiko kejadian barotrauma membran timpani pada kelompok penyelam tahan nafas pengais uang logam

\begin{tabular}{|c|c|c|c|}
\hline Variabel & $\mathrm{p}$ & RP & $95 \% \mathrm{CI}$ \\
\hline 1. Usia penyelam dewasa tua ( $\geq 17,5$ tahun) & 0,140 & 2,367 & $0,882-6,354$ \\
\hline $\begin{array}{l}\text { 2. IMT penyelam tidak normal } \\
\left(<18,5 \text { dan }>22,9 \mathrm{~kg} / \mathrm{m}^{2}\right)\end{array}$ & 0,216 & 0,476 & $0,178-1,277$ \\
\hline 3. Lama bekerja penyelam $\geq 5,5$ tahun & 0,622 & 1,440 & $0,546-3,795$ \\
\hline 4. Tingkat pendidikan penyelam rendah (SD-SMP) & 1,000 & 0,492 & $0,385-0,630$ \\
\hline $\begin{array}{l}\text { 5. Pengetahuan SOP safety dive } \\
\text { kurang baik }(\text { skor }<66)\end{array}$ & $<0,0001^{*}$ & 0,102 & $0,029-0,356$ \\
\hline 6. Frekuensi penyelaman sering (tiap hari menyelam) & 0,063 & 4,348 & $0,072-17,629$ \\
\hline 7. Kecepatan turun ke kedalaman $\geq 60$ feet & $0,003 *$ & 10,075 & $2,052-49,469$ \\
\hline 8. Kecepatan naik ke permukaan $\geq 60$ feet & 0,613 & 2,065 & $0,372-11,465$ \\
\hline 9. Kedalaman penyelaman $\geq 5$ Meter & 0,053 & 0,459 & $0,350-0,603$ \\
\hline $\begin{array}{l}\text { 10. Tidak memakai alat bantu selam } \\
\text { (mask, snorkel dan fins) }\end{array}$ & $0,010^{*}$ & 4,781 & $1,564-14,616$ \\
\hline $\begin{array}{l}\text { 11. Penghasilan penyelam rendah } \\
(<\mathrm{Rp} 1.240 .000 / \mathrm{bln})\end{array}$ & $0,007 *$ & 6,042 & $1,731-21,086$ \\
\hline
\end{tabular}

Tabel 3. Distribusi faktor risiko kejadian barotrauma membran timpani pada kelompok penyelam tradisional kompresor udara

\begin{tabular}{|c|c|c|c|c|}
\hline No. & Variabel & $\mathrm{p}$ & $\mathrm{RP}$ & $95 \% \mathrm{CI}$ \\
\hline & Usia penyelam dewasa tua ( $\geq 37$ tahun) & 0,093 & 3,109 & $0,969-9,973$ \\
\hline & $\begin{array}{l}\text { IMT penyelam tidak normal } \\
\left(<18,5 \text { dan }>22,9 \mathrm{~kg} / \mathrm{m}^{2}\right)\end{array}$ & 0,095 & 2,915 & $0,977-8,698$ \\
\hline & Lama bekerja ( $\geq 8$ tahun) & 0,476 & 1,667 & $0,593-4,682$ \\
\hline & Tingkat pendidikan penyelam rendah (SD-SMP) & 1,000 & 1,696 & $0,101-28,428$ \\
\hline & $\begin{array}{l}\text { Pengetahuan SOP safety dive } \\
\text { kurang baik ( } \text { skor }<66)\end{array}$ & 1,000 & 1,148 & $0,351-3,756$ \\
\hline & Frekuensi penyelaman sering (tiap hari bekerja) & $0,042 *$ & 4,200 & $1,204-14,650$ \\
\hline & Kecepatan turun ke kedalaman ( $\geq 18$ meter permenit) & $0,001 *$ & 0,121 & $0,035-0,415$ \\
\hline & Kecepatan naik ke permukaan ( $\leq 18$ meter permenit) & 0,639 & 1,667 & $0,459-6,056$ \\
\hline & Kedalaman penyelaman $\geq 1$ ATA & 0,093 & 0,322 & $0,100-1,032$ \\
\hline
\end{tabular}




\begin{tabular}{|c|c|c|c|}
\hline Variabel & $\mathrm{p}$ & RP & $95 \% \mathrm{CI}$ \\
\hline $\begin{array}{l}\text { 10. Tidak memakai alat bantu selam } \\
\text { (kompresor, regulator, masker, fins) }\end{array}$ & \multicolumn{3}{|c|}{2 sel kosong tidak bisa dianalisis } \\
\hline $\begin{array}{l}\text { 11. Penghasilan penyelam rendah } \\
(<\mathrm{Rp} 1.240 .000 / \mathrm{bln})\end{array}$ & $0,001^{*}$ & 0,121 & $0,035-0,415$ \\
\hline
\end{tabular}

Tabel. 4 Hasil analisis uji regresi logistik ganda pada penyelam tradisional tahan nafas pengais uang logam

\begin{tabular}{|c|c|c|c|c|}
\hline Variabel & B & $\mathrm{p}$ & $\overline{\mathrm{RP}}$ & $95 \% \mathrm{CI}$ \\
\hline $\begin{array}{l}\text { 1. Tidak memakai alat bantu selam } \\
\text { (kompresor, regulator, masker, fins) }\end{array}$ & 2.888 & 0,020 & 17,963 & $1,562-206,504$ \\
\hline $\begin{array}{l}\text { 2. Penghasilan penyelam rendah } \\
(<\operatorname{Rp} 1.240 .000 / \mathrm{bln})\end{array}$ & 2,262 & 0,018 & 9,600 & $1,471-62,652$ \\
\hline
\end{tabular}

Tabel 5. Hasil analisis uji regresi logistik pada penyelam tradisional kompresor udara

\begin{tabular}{llccc}
\hline \multicolumn{1}{c}{ Variabel } & $\mathrm{B}$ & $\mathrm{p}$ & $\mathrm{RP}$ & $95 \% \mathrm{CI}$ \\
\hline $\begin{array}{l}\text { 1. Usia penyelam dewasa tua } \\
(\geq 37 \text { tahun })\end{array}$ & 1,876 & 0,025 & 6,524 & $1,268-33,559$ \\
\hline
\end{tabular}

\section{Pembahasan}

Hasil analisis multivariat menunjukkan bahwa penyelam tradisional kelompok tahan nafas pengais uang logam dengan kecepatan turun 18 meter permenit terbukti secara statistik berpengaruh terhadap kejadian barotrauma membran timpani, ditunjukkan dengan nilai $p=0,020$. Setelah di lakukan perhitungan berdasarkan katagori kecepatan turun 18 meter permenit dan $<18$ meter permenit memiliki ratio prevalence 17,96 kali dibandingkan dengan kecepatan turun $<18$ meter permenit. Di dukung pula dengan hasil pengamatan dan indepth interview:

Pengamatan : penyelam uang logam sebagian besar penyelam banyak yang melompat dari atas dermaga kapal saat memulai penyelaman. Penyelam saat menangkap uang logam banyak berebut menyelam untuk menangkap. Mayoritas dewasa muda dan banyak tidak memakai alat bantu selam, hasil tangkapan saat berenang banyak di simpan di dalam mulut terutama anak-anak.

In-depth interview : saya terjun dari atas dermaga kapal dulu lalu berenang sambil menunggu para penumpang kapal fery/rombongan penumpang dari bis melemparkan uang logam ke laut, jika ada yang melempar uang logam saya dan teman-teman beramai-ramai berebut menyelam lebih dulu menangkap uang logam sudah kepegang saya cepat-cepat kembali kepermukaan. Jika penumpang kapal fery melemparkan uang logam jauh dari saya tetap saya kejar beramai-ramai menyelam bila tidak ketangkap saya naik kepermukaan dulu kemudian saya cepatcepat menyelam kembali untuk menangkap uang logam kemudian naik kepermukaan. Kegiatan ini sering saya lakukan untuk mendapatkan uang yang banyak, tidak sedikit saya dan teman-teman pada waktu menyelam telinga terasa sakit saya teruskan untuk menangkap uang logam.

Hasil penelitian ini sesuai dengan teori hukum Boyle bahwa kecepatan turun sangat berpengaruh terhadap rongga telinga, terutama kedalaman 1 ATA (kedalaman 10 meter pertama) kemudian kedalaman selanjutnya mengalami penurunan tekanan sesuai dengan hukum Boyle. ${ }^{7,14}$

Hasil analisis multivariat menunjukkan bahwa penyelam tradisional kelompok tahan nafas pengais uang logam dalam penyelaman tidak memakai alat bantu selam terbukti secara statistik sebagai faktor risiko yang berpengaruh terjadinya barotrauma membran timpani, ditunjukan dengan nilai $p=0,018$. Setelah di lakukan 
perhitungan besar risiko berdasarkan katagori penyelam tidak memakai alat bantu selam dan memakai alat bantu selam memiliki ratio prevalence sebesar 9,6 kali dibandingkan dengan penyelam yang memakai alat bantu selam. Didukung pula dengan hasil pengamatan dan indepth interview:

Pengamatan : "Hasil pengamatan dilokasi pelabuhan Ketapang Banyuwangi menunjukkan bahwa penyelam tahan nafas pengais uang logam mayoritas tidak memakai alat bantu selam. Penyelam yang memakai alat bantu selam terdiri dari, masker dan sepatu katak kondisinya kurang baik"

In-depth interview : "Menurut saya peralatan selam harganya mahal, dan tidak ada di toko peralatan selam di Banyuwangi yang ada di Kota Surabaya dan Denpasar. Saya menyelam lebih mudah melakukan penyelaman tanpa alat bantu selam, saya pernah mencoba punya teman rasanya tidak nyaman dipakai menyelam". Masalahnya memulai menyelam sering melompat dari dermaga kapal fery sambil atraksi menarik simpati para penumpang untuk melemparkan uang logam.

Hasil penelitian ini sejalan dengan penelitian yang dilakukan oleh Ekowati, yang menunjukkan bahwa nelayan penyelam tradisional yang tidak memakai alat bantu selam mempunyai risiko sebesar $0,82 \mathrm{kali}$ dibandingkan dengan nelayan penyelam tradisional yang memakai alat bantu selam. ${ }^{3}$ Penelitian lain yang sama juga dilakukan oleh Kartono menunjukkan bahwa nelayan penyelam tradisional yang tidak memakai alat bantu selam mempunyai risiko sebesar 1,5 kali lebih tinggi terjadinya barotrauma membran timpani di bandingkan penyelam yang tidak memakai alat bantu selam. ${ }^{15}$

Hasil analisis multivariat menunjukkan bahwa pada kelompok penyelam tradisional kompresor udara dengan katagori usia penyelam dewasa tua ( 37 tahun) yang terbukti secara statistik sebagai faktor risiko terjadinya barotrauma membran timpani, ditunjukkan dengan nilai $p=0,025$. Setelah di lakukan perhitungan besar risiko berdasarkan katagori usia penylam dewasa tua dan dewasa muda memiliki ratio prevalence sebesar $6,25 \mathrm{kali}$ dibandingkan dengan penyelam berusia dewasa muda.

Hasil penelitian ini berbeda dengan penelitian yang dilakukan Mao-Cheng Wong et.al, menunjukkan bahwa perenang yang di lakukan pada anak-anak sampai remaja (dewasa muda) terjadi barotrauma telinga sampai ruptur membran timpani dengan $\mathrm{p}<$ 0,05 . $^{16}$ Hasil penelitian ini sejalan dengan penelitian Thritz dan kadir dalam penelitian menjelaskan usia penyelam terbanyak pada kelompok umur 26 -30 tahun sebesar 31,8\%. 17

Faktor risiko usia penyelam dalam kesehatan penyelaman pada dasarnya tidak ada batasan usia yang tegas asalkan memenuhi persyaratan kesehatan, dimana usia penyelam yang ideal dalam melakukan penyelaman antara usia $16-35$ tahun. Usia merupakan karakteristik individu yang dapat mempengaruhi prilaku penyelaman. Prilaku penyelam yang tidak sesuai SOP safety dive berdampak secara langsung pada beberapa organ tubuh terutama rongga telinga. Usia juga memegang peranan penting dalam menerima informasi dan mengelola informasi dalam membuat keputusan demi keamanan dan kenyamanan penyelaman (safety dive). ${ }^{4,18}$

\section{Kesimpulan}

Terbukti secara statistik kejadian barotrauma membran timpani pada kelompok penyelam tahan nafas pengais uang logam adalah kecepatan turun 18 meter per menit didukung dengan data kualitaif (indepth interview) yaitu kami memulai menyelam dengan cara melompat dari atas dermaga kapal dengan ketinggian \pm 5 meter dan berebut menyelam untuk menangkap uang logam yang dilempar para penumpang kapal fery, jika uang logam tersebut belum tertangkap, kami dengan cepat menyelam kembali untuk menangkap uang tersebut yang masih melang-layan di dalam air sedangkan tidak memakai alat bantu selam 
(mask snorkel dan fins) didukung dengan data kualitatif (indepth interview) yaitu kami tidak mampu membeli peralatan selam karena harganya mahal dan mengurangi kecepatan turun pada waktu mengambil uang logam. Pada kelompok penyelam kompresor udara dengan usia penyelam dewasa tua 37 tahun didukung dengan data kualitatif (indepth interview) yaitu kami sudah berusia $>37$ tahun.

Beberapa faktor risiko yang tidak terbukti berpengaruh pada penyelam tradisional tahan nafas pengais uang logam adalah usia penyelam dewasa tua ( 17,5 tahun), indeks masa tubuh tidak normal $(<$ 18,5 dan $\left.>22,9 \mathrm{~kg} / \mathrm{m}^{2}\right)$, lama bekerja ( 5,5 dan 8 tahun), tingkat pendidikan penyelam rendah SD-SMP, tingkat pengetahuan SOP safety dive penyelam kurang baik (skor <66), Frekuensi penyelaman sering (tiap hari bekerja), kecepatan naik 60 feet, kedalaman penyelaman 5 meter dan penghasilan penyelam rendah $1.24000 / \mathrm{bln}$ sedangkan pada penyelam tradisional kompresor udara adalah indeks masa tubuh tidak normal $(<$ 18,5 dan $\left.>22,9 \mathrm{~kg} / \mathrm{m}^{2}\right)$, lama bekerja ( 5,5 dan 8 tahun), tingkat pendidikan penyelam rendah SD-SMP, tingkat pengetahuan SOP safety dive penyelam kurang baik (skor <66), Frekuensi penyelaman sering (tiap hari bekerja), kecepatan turun 60 feet, kecepatan naik 60 feet, kedalaman penyelaman 20 meter, dan penghasilan penyelam rendah $1.24000 / \mathrm{bln}$.

\section{Ucapan Terimakasih}

Terimakasih kepada penyelam tradisional Desa Ketapang dan Bangsring Kabupaten Banyuwangi yang telah bersedia menjadi responden penelitian serta berbagai pihak yang telah membantu proses pengumpulan data.

\section{Daftar Pustaka}

1. Adrianto L, A., Luky. Pembangunan dan Pengelolaan Pulau-Pulau Kecil yang berkelanjutan, in Makalah disampaikan pada pelatihan Perencanaan dan pengelolaan Wilayah Pesisir secara terpadu. Bogor. 2004.

2. Dermawan, A., Arif Miftahul Aziz. Pembangunan Minawisata Pulau-Pulau Kecil untuk Mendukung Implikasi Blue Economi. 2012.

3. Ekawati, Tesis. Analisis Faktor Risiko Barotrauma Membran Timpani pada Nelayan Penyelam Tradisional Semarang Utara in Pasca Sarjana Program Studi Ilmu Kesehatan Lingkungan. 2005, Universitas Diponegoro: Semarang.

4. Departemen Kesehatan R.I, Direktorat Jenderal Pengendalian Penyakit dan Penyakit Lingkungan. Petunjuk Teknis Upaya Kesehatan Penyelaman dan Hiperbarik bagi petugas kesehatan Propinsi, kabupaten/kota dan Puskesmas. 1 ed. 2008, Jakarta. h. 1-16.

5. Pusat Kesehatan Kerja, Departemen Kesehatan R.I. Pedoman Upaya Kesehatan Kerja Bagi Nelayan Penyelam Tradisional, Panduan Bagi Petugas Kesehatan. 2002, Jakarta: h.121.

6. Edmonds Carl, B.T., Bart McKenzie, John Pennefather. Diving Medicine for Scuba Divers 5th edition 2013 Published by Carl Edmonds Ocean Royale, 11/6974 North Steyne. Manly, NSW, 2095 Australia ISBN: 978-0-646-52726-0. 2012.

7. Riyadi, S., R Ilmu Kesehatan Penyelaman dan Hiperbarik,1 ed. 2013, Surabaya: Lakesla.

8. Germenpore, p. The Medical Risk of Underwater Diving and Their Control J. International Spord Medicine, 2006. p. 2-7.

9. Supartono, G. Traped gas pada penerbangan yang tinggi. Cermin Dunia Kedokteran. 1981.

10. Martin, T.E. Clinical Aspects of Aeromedical Transport. Nuff|eld Department of Anaesthesia, John Radcliffe Hospital, Headley Way, Headington, Oxford OX39DU,UK, 2003. 14,131-140

11. Dinas Kelautan dan Perikanan Kabupaten Banyuwangi. Potensi Kelautan dan Pesisir Kabupten Banyuwangi. 
12. Bryaman A. Quantity and Quality in sosial Research. London: Unwin. dalam buku: Brennen, Julia, Memadu Metode Kualitatif dan Kuantitatif(terj.). Yogyakarta. Pustaka Pelajar. 2005 h. 81105. 1998

13. David G. Kleinbaun, L.L.K., Hal Morgenstern.Epidemiologic research. Prinsiple and Quantitative Methods. 1982, Belmont, California: Lifetime Learning.

14. Edmonds Carl, B.T., Bart McKenzie, John Pennefather. Ear Barotrauma. Diving Medicine for Scuba Divers, 2013.9: p. 1-9.

15. Kartono, S.A. Tesis. Prevalensi dan Faktor Risiko Kejadian Penyakit Decompresi dan Barotrauma pada Nelayan Penyelam Tradisional di Kecamatan Karimunjawa in Program Pasca Sarjana Program Studi Ilmu Kesehatan Masyarakat Peminatan Epidemiologi Lapangan 2007, Fakultas Kedokteran Universitas Gajah Mada Yogyakarta: Yogyakarta.
16. Mao Che Wang, C.Y.L.,An Suey Shiao, Tyrone Wang. 2005. Ear Problems in Swimmers.J. Chin Med Assoc.2005.68(8). pp.347-353.

17. Thiritz D, K.A. 2005. Gangguan Pendengaran dan Keseimbangan pada Penyelam Suku Bajo Sulawesi Selatan. J.Medis Nus.26(3).pp.143-148

18. Departemen Kesehatan R I .2002.Ped oman Upaya Kesehatan Kerja BagiNelayan Penyelam Tradisional. Panduan Bagi Petugas Kesehata Jakarta.pp.1-21. 